\title{
Patient satisfaction with health care in an oncology setting
}

Zadowolenie pacjenta z opieki medycznej na oddziałach onkologicznych

\author{
Andrea Obročníková, L’udmila Majerníková
}

Department of Nursing, Faculty of Health Care, University of Prešov, Slovakia

CORRESPONDING AUTHOR/AUTOR DO KORESPONDENCJ:

Andrea Obročníková

Faculty of Health Care in Prešov, University of Prešov

ul. Partizánska 1, 08001 Prešov, Slovak Republic

tel. +421517562460

e-mail: andrea.obrocnikova@unipo.sk

\section{STRESZCZENIE}

Słowa kluczowe:

ABSTRACT

Key words:

\section{ZADOWOLENIE PACJENTA Z OPIEKI MEDYCZNEJ NA OD DZIALACH ONKOLOGICZNYCH}

Cel pracy. Celem badania przekrojowego jest ocena zadowolenia pacjentów z opieki medycznej na oddziałach onkologii klinicznej i radioterapii onkologicznej Szpitala w Preszowie oraz Wschodniosłowackiego Instytutu Onkologii w Koszycach (Słowacja). Ocena zadowolenia pacjenta przyczynia się do identyfikowania usług, które powinny być stale ulepszane oraz do utrzymywania jakości świadczonej opieki zdrowotnej.

Materiał i metody. Do zebrania danych, użyto kwestionariusza EORTC IN-PATSAT 32 zawierającego odpowiedzi w pięciostopniowej skali Likerta. Z 64 zakwalifikowanych do niniejszego badania pacjentów przebywających na oddziałach onkologicznych powyżej tygodnia, wypełniono i zwrócono 63 kwestionariusze. Badano zadowolenie pacjenta w odniesieniu do jego płci, wieku oraz stanu cywilnego.

Wyniki. Pacjenci chorzy na nowotwór wykazali niski poziom zadowolenia z dostępu do szpitala i z komfortu na oddziałach. Pod względem obserwowanych zmiennych, niższy poziom zadowolenia ze świadczonej opieki (czas oczekiwania, dostęp do szpitala, komfort) odnotowano u pacjentów nie posiadających partnera życiowego.

Wnioski. Pacjenci wskazali na niedociągnięcia w obszarach takich jak, dostęp do opieki w kontekście dostępności transportu czy orientacji w placówkach medycznych. Otoczenie placówek medycznych również nie zostało wysoko ocenione. Te problemy są niezwykle istotne gdyż wpływają na przeżycia pacjentów. Osoby zarządzające organizacjami opieki zdrowotnej powinny skupić się na tych słabych punktach i podjąć kroki prowadzące do zwiększenia zadowolenia pacjentów z opieki medycznej.

jakość usług zdrowotnych, zadowolenie pacjenta, pacjenci onkologiczni, opieka zdrowotna w dziedzinie onkologii, oddział szpitalny

\section{PATIENT SATISFACIION WITH WEALTH CARE IN AN ONCOLOGY SETTNG}

Aim. The purpose of cross-sectional study is to investigate the patient satisfaction with health care services provided in inpatient departments of clinical oncology and radiation oncology at the Faculty Hospital in Prešov and at East Slovak Oncology Institute in Košice (Slovakia). The assessment of patient satisfaction contributes to identification of services (factors) which are needed to be constantly improved and to maintenance of the quality of provided healthcare.

Material and methods. For the collection of data a questionnaire EORTC IN-PATSAT 32 with closed answers in a five-point Likert scale was used. Out of 64 recruited patients, who were hospitalized in oncology departments over a week, 63 returned a completed questionnaire. Patient satisfaction was assessed in relation to gender, age, marital status.

Results. patients reported low satisfaction with the hospital access and comfort in inpatients. In terms of the monitored variables, women and patients without life partner reported a lower level of satisfaction with providing care (waiting time, hospital access, comfort).

Conclusions. Patients referred to the deficits in health care in areas such as worse access to care in terms of transport accessibility and orientation in health care facilities. At the same time the environment was not rated high value. These defects are very important elements that significantly affect the survival of cancer patients. The management of health organization should focus attention on this issue and implement internal measures to improve patient satisfaction.

quality of health services, patient satisfaction, oncology patients, oncology health care, inpatient department 


\section{INTRODUCTION}

The quality of healthcare is often monitored attribute in health service. The quality of care has been defined as the degree to which health services for individual or populations increase the likelihood of desired health outcomes and are consistent with current professional knowledge [1]. The last three decades have seen an evolution in the assessment of cancer care. Cancer care quality can be characterized from the patient's perspective, or from the provider's perspective. The patient and provider may have different perspectives regarding the severity of cancer treatment side effects, wherein these separate perspectives may reflect distinct components of the quality of care received.

In the context of quality of healthcare perception, health services are of intangible character and the human factor plays a big role here, especially in direct contact with patients. The overall assessment of the quality of health care constitutes an assessment of various aspects, such as quality of medical care, nursing care, staff behavior and evaluation of internal environment of the medical facility. The patient very sensitively perceives care, informal interest, decency and competencies of health professionals. This confirms that the requirements for quality management in health care services are even more extreme than in the manufacturing plant [2]. Patient satisfaction can be influenced by a variety of external and internal influences. Satisfaction with care can comprise two different components: satisfaction with the care process and satisfaction with the care outcome. The components of the satisfaction with care process include waiting time, provision of information, access to care, adequacy of care environment, speed of treatment. The further domain of patient satisfaction, which is satisfaction with care outcome, includes perception of expectation. If patients' outcomes are either below their own perception of expectation or they have experiences with adverse treatment effects, they may be less satisfied with the care they have been provided. Admittedly, the factors that influence satisfaction with care in relation to cancer disease include cancer control, health-related quality of life, side effects of treatment, recovery, financial outcomes, quality of death, highlighting the multidimensionality of satisfaction with cancer care. Physical function, ability to perform daily activities, psychological well-being, side effects of treatment, symptoms (pain, fatigue, shortness of breath) cause changes in specific treatment and complicate the patient's satisfaction with outcome of care [3]. Satisfaction is an abstract and multidimensional concept, which is difficult to observe or measure, therefore it should be evaluated using a variety of multi-item scales [4].

\section{AIM}

The aim of the present study was to rate patient satisfaction with health care services provided in inpatient departments of clinical oncology and radiation oncology in Slovakia.

\section{MATERIAL AND METHODS}

A quantitative, cross-sectional descriptive design was used. Patient satisfaction with health care was measured with a questionnaire, which was developed within the European Organization of Research and Treatment of Cancer (EORTC) - the EORTC IN-PATSAT32 (Cancer inpatient satisfaction questionnaire). It was designed to evaluate the cancer inpatient's perception of the quality of medical and nursing care, as well as the organization care and services during admission to an oncology department. Questionnaire is organized into eleven multi-item scales and three single-item scales, including measurement of: doctor's technical skills (item 1 - 3), interpersonal skills (items 4 -6), information provision (items 7 - 9), availability (items 10 - 11); nurse's interpersonal skills (items 15 - 17), technical skills (items 12 - 14), information provision (items 18 - 20), availability (items $21-22$ ); other hospital personnel's kindness, helpfulness, information provision (items $24-26$ ); waiting time for medical tests, treatment and receiving test results (items $27-28$ ); access to hospital (items 29 - 30); exchange of information (item 23); comfort (item 31); and general satisfaction with care (item 32). Items are rated on a 5-level Likert scale as follows: 1 - poor, 2 - fair, 3 - good, 4 - very good, 5 - excellent. A higher score reflected a higher level of satisfaction with care [5]. The questionnaire included additional items such as socio - demographic information of respondents (age, gender, marital status) and duration of treatment. The time to complete the questionnaire took an average of 15 minutes.

Participants were given oral and written information about the aim of the study and the assessment to be conducted. Each patient who agreed to participate in a survey, completed the questionnaire according to the previous instruction. During the survey, 64 questionnaires were distributed personally to hospitalized cancer patients, but one questionnaire was excluded for incomplete filling all items. The selection criteria for survey sample were: patient age over 20 years, hospitalized inpatient with diagnosed cancer, hospitalization in oncology departments over a week long period of time, willingness of the patient to complete the questionnaire, inpatient with full consciousness without psychiatric illness. Data collection was conducted on clinical oncology and radiation oncology wards at the Faculty Hospital in Prešov and at East Slovak Oncology Institute in Košice from November 2015 to February 2016 in Slovakia. The data was processed using the statistical program SPSN 15.0. software. Statistical analysis and evaluation of empirical data has been realized in Microsoft Office Excel 2007 program and by using descriptive statistics absolute frequency $(n)$, arithmetic average (A) and standard deviation (SD). For statistical comparison of the variables, we used the t-test (Student's t distribution). 


\section{Ethical requirements/consideration}

Before data collection, permission to conduct the survey was obtained from Ethics Committee of the Faculty Hospital J. A. Reiman Prešov and the East Slovak Oncology Institute Košice. Participation in the study was voluntary and anonymous. Moreover, each participant (inpatient) was notified about the purpose of the study, the right to refuse to participate in the study and anonymity and confidentiality of the information gathered. Then, informed consent for participation in the study was signed by each participant.

\section{RESULTS}

The research sample consisted of 63 inpatients. Out of theoe 63 patients, 35 (55.56\%) were female and 28 (44.44\%) were male. The patients varied in age from 21 to 76 years, the largest group consisted of respondents aged 60 and over $-29(46.03 \%)$. Forty-two patients $(66.67 \%)$ were married, 7 (11.11\%) single, 7 (11.11\%) divorced and 7 (11.11\%) widowed. Out of the total sample, 25 (39.69\%) respondents were treated less than half a year, 21 (33.33\%) respondents were treated from six months to two years and $17(26.98 \%)$ respondents were treated more than two years.

In the individual tables (table 1-4) we present the results of our survey.

Tab. 1. Evaluation of patient's satisfaction.

\begin{tabular}{|l|c|c|c|c|c|}
\hline In-patsat32 & $\begin{array}{c}\text { Scales/single } \\
\text { items }\end{array}$ & Name of scales/items & $\mathbf{n}$ & $\mathbf{A}$ & SD \\
\hline Doctor's & 1 (q1-3) & technical skills & 63 & 4.34 & 0.81 \\
\hline & 2 (q4-6) & interpersonal skills & 63 & 4.16 & 0.89 \\
\hline & 3 (q7-9) & information provision & 63 & 4.23 & 0.92 \\
\hline & $4(\mathrm{q} 10-11)$ & availability & 63 & 4.09 & 0.93 \\
\hline Nurse's & 5 (q12-14) & technical skills & 63 & 4.32 & 0.79 \\
\hline & 6 (q15-17) & interpersonal skills & 63 & 4.28 & 0.87 \\
\hline & 7 (q18-20) & information provision & 63 & 4.25 & 0.78 \\
\hline & $8(\mathrm{q} 21-22)$ & availability & 63 & 4.23 & 0.82 \\
\hline 0ther areas & 9 (q24-26) & $\begin{array}{c}\text { other hospital staff, } \\
\text { interpersonal skills and } \\
\text { information provision }\end{array}$ & 63 & 4.13 & 0.81 \\
\hline & 10 (q27-28) & waiting time & 63 & 4.03 & 0.88 \\
\hline & $11(\mathrm{q} 29-30)$ & hospital access & 63 & 3.98 & 0.94 \\
\hline & $\mathrm{q} 23$ & $\begin{array}{c}\text { exchange of } \\
\text { information }\end{array}$ & 63 & 4.13 & 0.79 \\
\hline & $\mathrm{q} 31$ & comfort & 63 & 4.00 & 0.93 \\
\hline & $\mathrm{q} 32$ & general satisfaction & 63 & 4.22 & 0.89 \\
\hline
\end{tabular}

Patients showed a higher degree of satisfaction with the provision of nursing care versus medical care. The highest scores were found in the scales measuring doctor's technical skills and nurse's technical skills, as well as nurse's interpersonal skills, information provision from nurses. Scales regarding doctors' availability showed lower scores, as did waiting time, access and comfort.
Tab. 2. Evaluation of patient satisfaction according to gender.

\begin{tabular}{|c|c|c|c|c|c|c|c|c|}
\hline \multirow{3}{*}{ In-patsat32 } & \multirow{3}{*}{$\begin{array}{l}\text { Name of scales/ } \\
\text { items }\end{array}$} & \multicolumn{6}{|c|}{ Gender } & \multirow{3}{*}{$\mathbf{p}$} \\
\hline & & \multicolumn{3}{|c|}{ women } & \multicolumn{3}{|c|}{ men } & \\
\hline & & n & A & SD & $\mathbf{n}$ & A & SD & \\
\hline \multirow[t]{4}{*}{ Doctor's } & technical skills & 35 & 4.30 & 0.92 & 28 & 4.39 & 0.66 & 0.789 \\
\hline & interpersonal skills & 35 & 4.05 & 0.99 & 28 & 4.31 & 0.73 & 0.654 \\
\hline & information provision & 35 & 4.18 & 1.09 & 28 & 4.31 & 0.66 & 0.325 \\
\hline & availability & 35 & 4.06 & 1.03 & 28 & 4.14 & 0.80 & 0.547 \\
\hline \multirow[t]{4}{*}{ Nurse's } & technical skills & 35 & 4.27 & 0.87 & 28 & 4.40 & 0.68 & 0.872 \\
\hline & interpersonal skills & 35 & 4.21 & 0.99 & 28 & 4.37 & 0.69 & 0.851 \\
\hline & information provision & 35 & 4.24 & 0.81 & 28 & 4.26 & 0.73 & 0.943 \\
\hline & availability & 35 & 4.11 & 0.86 & 28 & 4.38 & 0.75 & 0.328 \\
\hline \multirow[t]{6}{*}{ 0ther areas } & $\begin{array}{c}\text { other hospital staff, } \\
\text { interpersonal skills } \\
\text { and information } \\
\text { provision } \\
\end{array}$ & 35 & 4.12 & 0.84 & 28 & 4.15 & 0.78 & 0.879 \\
\hline & waiting time & 35 & 3.97 & 0.98 & 28 & 4.11 & 0.76 & 0.087 \\
\hline & hospital access & 35 & 3.99 & 0.97 & 28 & 3.98 & 0.90 & 0.948 \\
\hline & $\begin{array}{l}\text { exchange of } \\
\text { information }\end{array}$ & 35 & 4.06 & 0.80 & 28 & 4.21 & 0.79 & 0.058 \\
\hline & comfort & 35 & 3.97 & 1.04 & 28 & 4.04 & 0.79 & 0.652 \\
\hline & general satisfaction & 35 & 4.17 & 0.98 & 28 & 4.29 & 0.76 & 0.745 \\
\hline
\end{tabular}

In terms of gender, women rated more stringently care provided by doctors, nurses, hospital staff, etc. Lowest satisfaction was expressed for waiting time, comfort and access by both women and men.

Tab. 3. Evaluation of patient satisfaction according to age.

\begin{tabular}{|c|c|c|c|c|c|c|c|c|}
\hline \multirow{3}{*}{ In-patsat32 } & \multirow{3}{*}{$\begin{array}{c}\text { Name of scales/ } \\
\text { items }\end{array}$} & \multicolumn{6}{|c|}{ Age } & \multirow{3}{*}{$\mathbf{p}$} \\
\hline & & \multicolumn{3}{|c|}{ 20-59 } & \multicolumn{3}{|c|}{60 and older } & \\
\hline & & $n$ & $A$ & SD & $n$ & A & SD & \\
\hline \multirow[t]{4}{*}{ Doctor's } & technical skills & 34 & 4.44 & 0.68 & 29 & 4.22 & 0.93 & 0.758 \\
\hline & interpersonal skills & 34 & 4.19 & 0.78 & 29 & 4.14 & 1.01 & 0.875 \\
\hline & information provision & 34 & 4.26 & 0.89 & 29 & 4.21 & 0.97 & 0.901 \\
\hline & availability & 34 & 4.00 & 0.85 & 29 & 4.21 & 1.02 & 0.123 \\
\hline \multirow[t]{4}{*}{ Nurse's } & technical skills & 34 & 4.47 & 0.67 & 29 & 4.16 & 0.89 & $0.042^{*}$ \\
\hline & interpersonal skills & 34 & 4.41 & 0.69 & 29 & 4.13 & 1.02 & 0.064 \\
\hline & information provision & 34 & 4.33 & 0.72 & 29 & 4.15 & 0.83 & 0.235 \\
\hline & availability & 34 & 4.35 & 0.79 & 29 & 4.09 & 0.84 & 0.136 \\
\hline \multirow[t]{6}{*}{ Other areas } & $\begin{array}{c}\text { other hospital staff, } \\
\text { interpersonal skills } \\
\text { and information } \\
\text { provision }\end{array}$ & 34 & 4.18 & 0.81 & 29 & 4.09 & 0.82 & 0.587 \\
\hline & waiting time & 34 & 4.03 & 0.88 & 29 & 4.03 & 0.90 & 0.987 \\
\hline & hospital access & 34 & 3.90 & 0.88 & 29 & 4.09 & 1.00 & 0.347 \\
\hline & $\begin{array}{l}\text { exchange of } \\
\text { information }\end{array}$ & 34 & 4.18 & 0.83 & 29 & 4.07 & 0.75 & 0.684 \\
\hline & comfort & 34 & 4.09 & 0.83 & 29 & 3.90 & 1.05 & 0.351 \\
\hline & general satisfaction & 34 & 4.21 & 0.77 & 29 & 4.24 & 1.02 & 0.786 \\
\hline
\end{tabular}

In terms of age, we observed a higher satisfaction with care among respondents aged up to 59 years, except for aspects such as doctor's availability, access, general satisfaction. In this group there was recorded a statistically significant value of professional skills of nurses. 
Tab. 4. Evaluation of patient's satisfaction by marital status.

\begin{tabular}{|c|c|c|c|c|c|c|c|c|}
\hline \multirow{3}{*}{ In-patsat32 } & \multirow{3}{*}{$\begin{array}{c}\text { Name of scales/ } \\
\text { items }\end{array}$} & \multicolumn{6}{|c|}{ Marital status } & \multirow{3}{*}{$\mathbf{p}$} \\
\hline & & \multicolumn{3}{|c|}{\begin{tabular}{|c|}
$\begin{array}{c}\text { without a life } \\
\text { partner }\end{array}$ \\
\end{tabular}} & \multicolumn{3}{|c|}{$\begin{array}{c}\text { with a life } \\
\text { partner }\end{array}$} & \\
\hline & & $\mathbf{n}$ & A & SD & $\mathbf{n}$ & A & SD & \\
\hline \multirow[t]{4}{*}{ Doctor's } & technical skills & 21 & 4.22 & 1.02 & 42 & 4.40 & 0.68 & 0.179 \\
\hline & interpersonal skills & 21 & 4.05 & 1.07 & 42 & 4.22 & 0.79 & 0.479 \\
\hline & $\begin{array}{c}\text { information } \\
\text { provision }\end{array}$ & 21 & 4.21 & 0.99 & 42 & 4.25 & 0.89 & 0.931 \\
\hline & availability & 21 & 4.00 & 0.99 & 42 & 4.14 & 0.91 & 0.331 \\
\hline \multirow[t]{4}{*}{ Nurse's } & technical skills & 21 & 4.24 & 0.95 & 42 & 4.37 & 0.70 & 0.774 \\
\hline & interpersonal skills & 21 & 4.21 & 1.11 & 42 & 4.31 & 0.72 & 0.527 \\
\hline & $\begin{array}{l}\text { information } \\
\text { provision }\end{array}$ & 21 & 4.17 & 0.83 & 42 & 4.29 & 0.75 & 0.862 \\
\hline & availability & 21 & 4.19 & 0.89 & 42 & 4.25 & 0.79 & 0.400 \\
\hline \multirow[t]{6}{*}{ Other areas } & $\begin{array}{c}\text { other hospital staff, } \\
\text { interpersonal skills } \\
\text { and information } \\
\text { provision }\end{array}$ & 21 & 4.08 & 0.92 & 42 & 4.17 & 0.76 & 0.774 \\
\hline & waiting time & 21 & 4.02 & 1.05 & 42 & 4.03 & 0.80 & 0.927 \\
\hline & hospital access & 21 & 4.00 & 0.94 & 42 & 3.98 & 0.94 & 0.790 \\
\hline & $\begin{array}{l}\text { exchange of } \\
\text { information }\end{array}$ & 21 & 4.14 & 0.91 & 42 & 4.11 & 0.74 & 0.547 \\
\hline & comfort & 21 & 3.81 & 1.12 & 42 & 4.10 & 0.82 & 0.182 \\
\hline & general satisfaction & 21 & 4.05 & 1.12 & 42 & 4.31 & 0.75 & 0.327 \\
\hline
\end{tabular}

Perceived satisfaction with the care provided is affected by marital status. Higher satisfaction with care by doctors, nurses and hospital staff was observed in patients living with life partner than those without a partner. Lower level of satisfaction achieved the following aspects: comfort, hospital access, waiting time.

\section{DISCUSSION}

A majority of the population perceives cancer, especially malignant, as a disease that is accompanied by pain and suffering, loss of vital power, helplessness and impending death [6]. The disease has an impact on patient's psyche and may alter his personal characteristics. It affects his actual survival, thinking and behaviour, as described in phases of survival by Kübler-Ross.

Cancer patients seek help in health care workers [7]. Creating balanced and confidential relationship between caregivers and patients leads to strengthening the feeling of security and safety [8]. The patient's attitude towards disease is a decisive moment which determines the course of every treatment. The positive attitude of the patient is influenced by the approach of doctors and nurses to him, depending on their professional and interpersonal skills.

The patient has the right to open communication, as mutual communication helps him to understand the situation and also prevents the genesis of negative emotions such as anxiety, stress, fear, etc. Sufficient information is a prerequisite for better patient compliance.

Source of information about health condition, efficacy of the treatment or change of treatment is the patient's doctor. Those pieces of information are very important for cancer patient, especially how they are passed to the patient. On the other side, the information deficit can cause aggression, dissatisfaction, verbal complaints, questions, requests for information [9]. Participants of our study would require better availability in the meaning of time and frequency of needed consultations. Despite the above mentioned fact, leading finding of the study is that patients expressed satisfaction with care provided by doctors and nurses in surveyed aspects.

Results of the study pointed to deficiencies in care concerning the hospital access, comfort during hospitalization and waiting time. Long waiting time is a major source of patient dissatisfaction and can negatively affect patient compliance with treatment modes and clinical outcomes [10]. Cancer patients require longer consultation times, what have a build up effect of increasing waiting time of the other patients to be seen.

\section{Patient satisfaction according to socio- demographic characteristics}

The results of this study showed that no statistical relationship was found between gender and patients' satisfaction, but they recorded men tendency to be more satisfied than women with nursing and medical care, information, hospital environment.

We should not forget that the oncologic disease significantly affects not just the patient life, but also the lives of family members, his relationships with individual members of family and social relationships and it also has a major impact on patient quality of life. Similarly, no significant correlation was observed between marital status and satisfaction, although a higher level of satisfaction reported patients living with a partner, except for hospital access and exchange of information. Higher satisfaction may be explained by the fact that undoubtedly patient copes with the disease and cancer treatment better if has an important person (life partner, support person) who proves the patient support and understanding [11].

Looking at the age of respondents, there was one significantly confirmed relationship in the aspect of technical nursing skills. Younger patients reported higher satisfaction in nursing procedures, nursing examinations and ensuring their comfort during hospitalization. Because we did not focus on attributes such as performance status, patient self-sufficiency and other physical and psychological effects of treatment, we consider that worse satisfaction may be related to higher dependency on health workers. The results of studies $[12,13]$ reported association between age and satisfaction too, but in this study they were found to report a slightly higher satisfaction in older patients than younger patients. Their findings explain that older people are placing greater value on the nursing care they receive when their own need of care is at its greatest.

In summary, positive finding of this study is that patients expressed satisfaction with care provided by doctors and nurses and also in majority satisfactorily identified factors of institution's organization associated with patient satisfaction (waiting time, hospital access, comfort). From a management perspective, it may contribute to underlining priorities in sphere of investments for health care organizations. In our study, waiting time 
(for booking an appointment or to reach a caregiver by phone) and the physical environment of the hospital (access, comfort) were the aspects with the lowest levels of patient satisfaction. These findings could support a request for more human resources and a project to extend parking capacities.

Based on the results of the study we propose the following practical recommendations for management of health institution:

- to improve access, car parks at the hospital for inpatients and their relatives,

- to improve the orientation of patients and their relatives in the buildings of the hospital environment, the standard information schema (tables, label, posters),

- to allow disabled access in all the healthcare area, ensuring equipment enabling movement in exterior and interior of health care unit,

- promotion the implementation of new projects and obtaining grants for the restoration and revitalization of the interior and exterior,

- to establishment of a living room for visitors in order to preserve the privacy and intimacy during an interview with the patient's relatives.

\section{CONCLUSION}

Satisfaction with cancer care is definitely a subjective topic because it is the result of a combination of each patient's differing personality, expectations and care outcome. Satisfaction is the final subdomain of the patient perspective and is jointly influenced by health-related quality of life and health state. Patient-reported satisfaction provides a system of checks and balances against the unfair provider perspective [14]. Quality of life is an important target of care provision in oncology (e.g. relieving disease or treatment-related symptoms); thus, it is important to assess whether patients are satisfied with interventions aimed at attenuating the burden of illness. Patient-reported satisfaction with care services is the ultimate validator of quality care and its quantification is thus a crucial step in assessing the health care system [15]. It is necessary to constantly improve the quality of health care, maintain and improve the image of the health professional (empathy, willingness to listen to patients' concerns, problems, communication with the patient) and to provide a comfortable environment for the patient.

\section{LIMITATION}

Major treatment toxicity and poorer perceived health status significantly predict lower levels of satisfaction with care and quality life. This variable has not been evaluated in our study. Building on the literature and clinical experiences in the evaluation of patient satisfaction is involved in a number of factors that we were not studied. Therefore, we recommend for future study with repeated measure to focus on variables such as quality of patient life, the toxicity of treatment (pain, fatigue, vomiting, diarrhoea), the number of nurses per hospital bed, the number doctors per hospital bed, the level of overall health, the education level of patients, the disease state, the focus of the treatment (curative, palliative) in relation to the patient satisfaction with health care.

\section{ACKNOWLEDGEMENTS}

We thank departments of clinical oncology and radiation oncology at the Faculty Hospital J. A. Reiman in Prešov and East Slovak Oncology Institute in Košice for support and affirmative opinions (consents) on research. We thank personnel working at departments and all patients who participated in this study.

\section{REFERENCES/PIŚMIENNICTWO}

1. Dennison CR. The role of patient-reported outcomes in evaluating the quality of oncology care. Am J Manag Care. 2002;8 (18 Suppl):580-586.

2. Pešek J. Tvorba systému jakosti ve zdravotníctví a lékárenství s využitím norem ISO. 1. vyd. Praha: Grada Publising; 2003, p.110.

3. Ganz PA. What outcomes matter to patients: a physician-researcher point of view. Med Care. 2002;40(6Suppl):III11-19.

4. Labarere J, Francois $P$, Auquier $P$, et al. Development of a french inpatient satisfaction questionnaire. International J Quality In Health Care. 2001;13(2): 99-108.

5. Brédart, A, Bottomley $A$, Blazeby JM, et al. An international prospective study of the EORTC cancer in-patient satisfaction with care measure (EORTC IN-PATSAT32). European Journal of Cancer. 2005;41(14):2120-2131.

6. Brédart $A$, et al. Determinants of patient satisfaction in oncology settings from European and Asian countries: Preliminary results based on the EORTC IN-PATSAT32 questionnaire. European Journal of Cancer. 2007; 43(2):323-330.

7. Davies E, Higginson IJ. Systematic review of specialist palliative day-care for adults with cancer. Support Care Cancer. 2005; 13(8):607-27.

8. Bártlová S, Hnilicová H. Vybrané metódy a techniky výzkumu. Zjistovaní spokojnosti pacietu. Brno: Institut pro dal'ší vzdělávání pracovníku ve zdravotníctví; 2000, s.118.

9. Berč A, Palková L'et al. Onkologické ošetrovatel'stvo I. 1. vyd. Košice: ZZ desing studio; 2008, s.182.

10. Yeboah E, Thomas M. A cost effective way of reducing outpatient clinic waiting times: How we did it. The Internet Journal of Healthcare Administration. 2009;7(1):1-4.

11. Tschuschke V. Psychoonkologie. 1. vyd. Praha: Portál; 2004, s.215.

12. Akhbari F, Hosseini M, Arab M, Chozokly N. Study of effective factors on inpatient satisfaction in Hospitals of Tehran University of medical science. Scientific Journal of School of Public Health and Institute of Public Health Research. 2006;4(3):25-36.

13. Hajifathali A, Ainy A, Jafari $H$, et al. In-patient satisfaction and its related factors in Taleghani University hospital, Tehran, Iran. Pak J Med Sci. 2008;24(2):274-277.

14. Arvin Koruthu George BA, Martin G, Sanda MD. Measuring Patient Satisfaction. In Clinical Research for Surgeons. Editors: Penson DF, Wei JT. 2007, p.253-265.

15. Schwartz CE, Sprangers MA. An introduction to quality of life assessment in oncology: the value of measuring patient-reported outcomes. Am J Manag Care. 2002;18(Suppl):S550-S559.

Manuscript received/Praca przyjęta do druku: 09.12.2016

Manuscript accepted/Praca zaakceptowana do druku: 09.03.2017

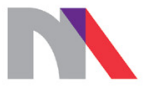

Ministerstwo Nauki

i Szkolnictwa Wyższego

„Konsultacje z zagranicznymi naukowcami i wprowadzenie dwujęzycznych (j. polski/angielski) treści do czasopisma Pielęgniarstwo XXI wieku" finansowane w ramach umowy 547/P-DUN/2016 ze środków Ministra Nauki i Szkolnictwa Wyższego przeznaczonych na działalność upowszechniającą naukę. 